\title{
Modulation of the Antioxidant Defense System by Exogenous L-Glutamic Acid Application Enhances Salt Tolerance in Lentil (Lens culinaris Medik.)
}

\author{
Jannatul Fardus, Md. Shahadat Hossain and Masayuki Fujita * \\ Laboratory of Plant Stress Responses, Faculty of Agriculture, Kagawa University, Ikenobe 2393, Miki-Cho, \\ Kita Gun, Kagawa 761-0795, Japan; jannatulsau11@gmail.com (J.F.); shahadatsau24@gmail.com (M.S.H.) \\ * Correspondence: fujita.masayuki@kagawa-u.ac.jp
}

check for

updates

Citation: Fardus, J.; Hossain, M.S.;

Fujita, M. Modulation of the

Antioxidant Defense System by

Exogenous L-Glutamic Acid

Application Enhances Salt Tolerance in Lentil (Lens culinaris Medik.).

Biomolecules 2021, 11, 587. https://

doi.org/10.3390/biom11040587

Academic Editor: Mohamed

A. El-Esawi

Received: 22 March 2021

Accepted: 15 April 2021

Published: 16 April 2021

Publisher's Note: MDPI stays neutral with regard to jurisdictional claims in published maps and institutional affiliations.

Copyright: (C) 2021 by the authors Licensee MDPI, Basel, Switzerland. This article is an open access article distributed under the terms and conditions of the Creative Commons Attribution (CC BY) license (https:// creativecommons.org/licenses/by/ $4.0 /)$.

\begin{abstract}
Salt stress greatly disturbs the growth, morpho-physiological, and biochemical performance of plants. However, different physiological processes and acclimation mechanisms can be induced under stress, while some of them can be modulated by the appropriate chemical stimulus. The objective of this study was to evaluate the impact of exogenous pretreatment with $10 \mathrm{mM}$ L-glutamic acid (L-Glu) on the physiological and biochemical parameters of lentil (Lens culinaris Medik.) under $110 \mathrm{mM} \mathrm{NaCl}$ stress. Salt stress inhibited the growth and reduced the photosynthetic pigment (chlorophylls and carotenoids) level, water content, and survival of lentil seedlings during recovery from the stress. Salt stress also induced oxidative damage, as indicated by higher hydrogen peroxide and malonaldehyde contents and electrolyte leakage, by interrupting the antioxidant defense system and promoting the accumulation of toxic levels of $\mathrm{Na}^{+}$. However, L-Glu pretreatment mitigated the salt-induced damage in lentil seedlings by reducing the accumulation of $\mathrm{Na}^{+}$, maintaining ion homeostasis, and increasing the activities of antioxidant enzymes (catalase and ascorbate peroxidase). As a result, salt-induced oxidative damage was reduced, seedling growth and photosynthetic pigment contents were enhanced, and the survival rate of the lentil seedlings was improved in response to salt stress, indicating an ameliorative role for L-Glu in lentil seedling growth under salt stress.
\end{abstract}

Keywords: salt stress; ROS; oxidative damage; ion homeostasis; antioxidant defense system; amino acid

\section{Introduction}

Among the abiotic stresses experienced by crop plants, salinity is a major abiotic stress that affects about $20 \%$ of the world's total cultivable land, estimated at around 800 million hectares. Current estimates indicate that approximately half of the present-day cultivable land will be unsuitable for cultivation by the middle of the 21st century due to salinity, posing a serious threat to global crop production [1].

Exposure of plants to a soluble salt in excess of the threshold level $\left(4 \mathrm{dS} \mathrm{m} \mathrm{m}^{-1}\right.$ or higher) causes osmotic stress and reduces plant growth [2]. Ionic stress follows, with the increasing accumulation of toxic ions, mainly $\mathrm{Na}^{+}$and $\mathrm{Cl}^{-}$, and this leads to necrosis and death of the leaves from older to younger [1]. Both osmotic stress and ionic toxicity inhibit photosynthesis, disrupt ion homeostasis, inactivate vital enzymes, and increase the accumulation of reactive oxygen species (ROS), such as singlet oxygen $\left({ }^{1} \mathrm{O}_{2}\right)$, superoxide radical $\left(\mathrm{O}_{2} \cdot{ }^{-}\right)$, hydrogen peroxide $\left(\mathrm{H}_{2} \mathrm{O}_{2}\right)$, and hydroxyl radical $(\mathrm{OH} \cdot)$ [3,4]. ROS reduce photosynthetic ability, denature proteins, and promote the peroxidation of lipids, with subsequent death of the plants [1].

Under optimal growth conditions, a minimal level of ROS is generated in different plant organelles $[5,6]$. However, the generation of ROS increases in response to stress and causes oxidative bursts in the organelles of plants [7]. Plants cope with the damage caused by salt stress by activating antioxidant defense mechanisms that involve both nonenzymatic components (ascorbic acid (AsA), reduced glutathione (GSH), and oxidized 
glutathione (GSSG)) and enzymatic components (catalase (CAT), ascorbate peroxidase (APX), monodehydroascorbate reductase (MDHAR), dehydroascorbate reductase (DHAR), glutathione reductase (GR), glutathione peroxidase (GPX), and glutathione $S$-transferase (GST)) working in concert [7-10].

Evidence suggests that the accumulation of osmolytes (such as proline (Pro), glycinebetaine, and sugar alcohols), inhibition of $\mathrm{Na}^{+}$uptake, transport of $\mathrm{Na}^{+}$from the root to the shoot, restriction of $\mathrm{K}^{+}$leakage, and detoxification of ROS by the antioxidant defense system work synergistically to mitigate salt-induced damage in plants [1,11,12]. A few technologies have been established to enhance tolerance in plants to abiotic stresses, including salt stress [13-16]. For example, the use of chemicals can alleviate stress-induced damage without resorting to genetic alterations of crop plants $[17,18]$. Numerous studies now suggest an enhancement of salt stress tolerance in plants by several different chemicals [19-22], including gibberellic acid, salicylic acid, and $\gamma$-aminobutyric acid, in wheat, maize, and rice [23-26]. In recent times, a non-essential amino acid, glutamate (Glu), was found to play a vital role in plant growth and development processes (seed germination and pollen and root architecture) and in stress acclimation [27,28]. La et al. [27] suggested that exogenous application of Glu could enhance drought tolerance in radish. These findings suggested to us that L-Glu might increase salt tolerance in plants. However, the role of L-Glu in enhancing salt stress tolerance in important crop plants has not yet been investigated.

One particularly significant crop among the other pulse crops grown in Bangladesh is lentil (Lens culinaris) $[29,30]$. Lentil remains the most essential legume crops in many countries of the world due to its high protein content [31]. In addition, lentil plants can fix nitrogen from the atmosphere in the soil through root nodules [32]. However, lentil plants are sensitive to salt stress; therefore, increasing soil salinity has reduced the production of lentils worldwide and threatens the protein intake of large segments of the human population through its effects on soil health [33].

In the present study, we investigated the effect of exogenous application of L-Glu in mitigating salt-induced damage in lentil, as a less well-researched but economically important crop. We observed the plant growth, oxidative damage, and activity of different antioxidants during recovery from salinity stress. To the best of our knowledge, this is the first report showing the potential for the use of L-Glu to enhance salt stress tolerance in lentil.

\section{Materials and Methods}

\subsection{Plant Growing Conditions and Treatment}

Uniform seeds of lentil (Lens culinaris Medik cv. BARI Masur-7) were surface sterilized for $5 \mathrm{~min}$ using $70 \%$ ethanol, then dipped in distilled water for $24 \mathrm{~h}$ and placed on moistened six layers of paper towels in the Petri dishes and kept in dark conditions for $72 \mathrm{~h}$. Keeping 40 germinated seedlings per Petri plate, Petri plates were then transferred into the growth chamber under a photon flux density of $350 \mu \mathrm{mol} \mathrm{m}^{-2} \mathrm{~s}^{-1}$ with continuous illumination and $25 \pm 1{ }^{\circ} \mathrm{C}$ temperature. After $24 \mathrm{~h}$, two sets of Petri plate were provided with $10 \mathrm{mM}$ L-Glu along with Hyponex nutrient solution [34]. Another two sets of Petri plate were provided with only Hyponex (Tokyo, Japan) nutrient solution. Then 6-day-old seedlings were treated with $\mathrm{NaCl}(110 \mathrm{mM})$ with or without L-Glu pretreatment. The dose of L-Glu and salt stress was selected based on our preliminary trial and former report (Figures S1a-d and S2a-d) [35]. After 2 days of stress treatment, seedlings were allowed to recover by supplying nutrient solution only. Thus, the treatments were control (without $\mathrm{NaCl}$ ), $10 \mathrm{mM} \mathrm{L}-\mathrm{Glu}, 110 \mathrm{mM} \mathrm{NaCl}$ (S), and $110 \mathrm{mM} \mathrm{NaCl}$ with $10 \mathrm{mM}$ L-Glu (S + L-Glu), and each treatment had three replications. Finally, physiological, and biochemical parameters were measured from the seedlings. 


\subsection{Assessment of Survival Percentage}

We counted the fully recovered seedlings after 7 days of recovery for evaluating survival percentage following the formula of Gong et al. [36]. The formula was survival $(\%)=$ survived seedlings $\times 100 /$ total number of seedlings.

\subsection{Determination of Shoot Fresh Weight, Root Fresh Weight, Root Fresh Weight, Root Dry Weight and Water Content}

To estimate shoot and root fresh and dry weight, 10 shoots and roots of randomly selected seedlings were separated, and then fresh weight of shoot (SFW) and root (RFW) were determined after extra moisture was removed using a paper towel. Later, the same 10 seedlings were kept in a dryer for $48 \mathrm{~h}$ with $80^{\circ} \mathrm{C}$ temperature until showing constant weight and then the dry weight of three replications of shoot (SDW) and root (RDW) was recorded. Thereafter, water content (WC) was estimated by following the formula: $\mathrm{WC}(\%)=((\mathrm{FW}-\mathrm{DW}) / \mathrm{FW}) \times 100$.

\subsection{Evaluation of Chlorophyll and Carotenoid Content}

A leaf sample $(0.1 \mathrm{~g})$ was collected and put in a test tube containing $10 \mathrm{~mL}$ of DMSO. For the efficient extraction of chlorophylls (Chl) and carotenoids (Car), the test tube was placed in a water bath for heating for about $1 \mathrm{~h}$ with $65^{\circ} \mathrm{C}$ temperature. After $1 \mathrm{~h}$, the sample was kept in a room for cooling and then absorbance was measured at 665 and $649 \mathrm{~nm}$ wavelengths followed by the formula of Wellburn [37]. Following Wellburn [37], the absorbance of carotenoid (Car) content was measured at $480 \mathrm{~nm}$ wavelength. The expressing unit of Chls and Car was $\mathrm{mg} \mathrm{g}^{-1} \mathrm{FW}$.

\subsection{Measurement of Proline Content and Electrolyte Leakage}

According to Bates et al. [38], proline (Pro) content was measured from the shoot of each sample and expressed as $\mu \mathrm{mol} \mathrm{g}{ }^{-1} \mathrm{FW}$. The assessment of electrolyte leakage (EL) was done by following the method of Dionisio-Sese and Tobita [39].

\subsection{Estimation of Malonaldehyde, Other Aldehyde and Hydrogen Peroxide}

A total of $3 \mathrm{~mL}$ of ice-cold 5\% TCA (trichloroacetic acid) was used for homogenizing a $0.5 \mathrm{~g}$ shoot of plant sample while using a mortar and pestle and then centrifuged for $15 \mathrm{~min}$ at $11,500 \times \mathrm{g}$. After centrifugation, $1 \mathrm{~mL}$ of supernatant was mixed with $4 \mathrm{~mL}$ of TBA (thiobarbituric acid) and heated for $30 \mathrm{~min}$. After heating, the sample was kept in an ice box for cooling and then centrifuged again for $10 \mathrm{~min}$. Finally, this supernatant was used for estimating malonaldehyde (MDA) as the difference between absorbance at 532 and at $600 \mathrm{~nm}$, while the other aldehyde contents also determined the absorbance at $455 \mathrm{~nm}[40,41]$. MDA and other aldehyde contents were calculated using co-efficients of $155 \mathrm{mM}^{-1} \mathrm{~cm}^{-1}$ and $0.457 \times 10^{5} \mathrm{M}^{-1} \mathrm{~cm}^{-1}$, respectively. Measurement of hydrogen peroxide $\left(\mathrm{H}_{2} \mathrm{O}_{2}\right)$ was done according to Yang et al. [42] using the absorbance at $390 \mathrm{~nm}$.

\subsection{Assessment of Reduced Ascorbate, Reduced Glutathione, and Oxidized Glutathione Content}

The plant sample $(0.5 \mathrm{~g})$ was centrifuged for $15 \mathrm{~min}$ at $11,500 \times \mathrm{g}$ after homogenizing with $3 \mathrm{~mL}$ of $5 \%$ TCA. The supernatant was collected from the centrifuged sample, which was then used for the determination of ascorbate (AsA), total glutathione and oxidized glutathione (GSSG) followed by the method of Noctor et al. [43] through neutralizing with 0.5 M K-P (potassium phosphate) buffer at $\mathrm{pH} 7.0$ and expressed as $\mu \mathrm{mol} \mathrm{g}{ }^{-1} \mathrm{FW}$ and nmol g ${ }^{-1} \mathrm{FW}$.

\subsection{Measurement of Total Soluble Protein}

The concentration of total soluble protein was assayed and computed through using bovine serum albumin (BSA) as a standard of protein followed by the method of Bradford [44]. 


\subsection{Estimation of the Activity of Enzyme}

Firstly, $0.5 \mathrm{~g}$ of lentil shoots from each sample was taken in a mortar and pestle and homogenized with $50 \mathrm{mM}$ buffer containing ascorbate $(1 \mathrm{mM}), \mathrm{KCl}(100 \mathrm{mM}), \beta$ marceptoethanol $(5 \mathrm{mM})$ and glycerol $(10 \% w / v)$. After homogenizing, the sample was centrifuged at $11,500 \times \mathrm{g}$ for $15 \mathrm{~min}$ at $4{ }^{\circ} \mathrm{C}$ and the supernatant then transferred in an Eppendorf tube which was later used for estimating soluble protein concentration and the activity of enzymes.

The activity of catalase (CAT, EC:1.11.1.6) was measured as the absorbance at $240 \mathrm{~nm}$ with the addition of $\mathrm{H}_{2} \mathrm{O}_{2}$ and enzyme described by Noctor et al. [43] and computed using $40 \mathrm{mM}^{-1} \mathrm{~cm}^{-1}$ extinction coefficient; the expressing unit was $\mu \mathrm{mol} \mathrm{min}{ }^{-1} \mathrm{~g}^{-1}$ protein.

Ascorbate peroxidase (APX, EC:1.11.1.11) activity was estimated using extracted enzyme which mixed with K-P buffer $(50 \mathrm{mM})$ having $\mathrm{pH} 7.0$, AsA $(0.5 \mathrm{mM}), \mathrm{H}_{2} \mathrm{O}_{2}$ $(0.1 \mathrm{mM})$ and EDTA $(0.1 \mathrm{mM})$ at an absorbance of $290 \mathrm{~nm}$ and expressed as nmol $\mathrm{min}^{-1}$ $\mathrm{mg}^{-1}$ protein [43].

To assess the activity of monodehydroascorbate reductase (MDHAR, EC:1.6.5.4), Tris$\mathrm{HCl}$ buffer $(50 \mathrm{mM})$ at $\mathrm{pH} 7.5$, AsA $(2.5 \mathrm{mM})$ and NADPH $(0.2 \mathrm{mM})$ were added with extracted enzyme and measured the absorbance at $290 \mathrm{~nm}$. The unit of MDHAR was nmol $\mathrm{min}^{-1} \mathrm{mg}^{-1}$ protein and calculated using $6200 \mathrm{M}^{-1} \mathrm{~cm}^{-1}$ as an extinction co-efficient [43].

According to the formula of Noctor et al. [43], dehydroascorbate reductase (DHAR, EC:1.8.5.1) was measured as the absorbance at $265 \mathrm{~nm}$ after the addition of K-P buffer $(50 \mathrm{mM})$ at $\mathrm{pH} 7.0, \mathrm{GSH}(2.5 \mathrm{mM})$ and DHA $(0.1 \mathrm{mM})$ with extracted enzyme and expressed as $\mathrm{nmol} \mathrm{min} \mathrm{mg}^{-1} \mathrm{mg}^{-1}$ protein.

The activity of glutathione reductase (GR, EC:1.6.4.2) was assayed by following the method of Noctor et al. [43], where extracted enzyme was mixed with K-P buffer (20 mM) at pH 7.0, EDTA $(1 \mathrm{mM})$, GSSG $(0.1 \mathrm{mM})$ and NADPH $(1.35 \mathrm{mM})$, and absorbance was measured at $340 \mathrm{~nm}$ and computed by using a $6200 \mathrm{M}^{-1} \mathrm{~cm}^{-1}$ extinction coefficient. The activity was expressed as nmol $\mathrm{min}^{-1} \mathrm{mg}^{-1}$ protein.

To determine the activity of glutathione $S$-transferase (GST, EC:2.5.1.18), extracted enzyme was mixed with Tris- $\mathrm{HCl}$ buffer $(100 \mathrm{mM})$ at $\mathrm{pH}$ 6.5, GSH $(1.5 \mathrm{mM})$ and 1-chloro-2,4dinitrobenzene $(\mathrm{CDNB}, 1 \mathrm{mM})$ and the absorbance at $340 \mathrm{~nm}$. The activity was calculated by using $9600 \mathrm{M}^{-1} \mathrm{~cm}^{-1}$ as the extinction coefficient. The activity was expressed as nmol $\mathrm{min}^{-1} \mathrm{mg}^{-1}$ protein [45].

Glutathione peroxidase (GPX, EC:1.11.1.9) activity was estimated through using K-P buffer $(100 \mathrm{mM})$ at $\mathrm{pH} 7.0$, EDTA $(1 \mathrm{mM}), \mathrm{NaN}_{3}(1 \mathrm{mM})$, NADPH $(0.12 \mathrm{mM})$, GSH $(2 \mathrm{mM})$, GR (1 unit) and $\mathrm{H}_{2} \mathrm{O}_{2}(0.6 \mathrm{mM})$ with extracted enzyme by measuring the absorbance at

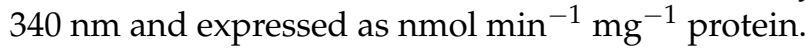

\subsection{Determination of Methylglyoxal Level}

Shoots $(0.25 \mathrm{~g})$ of lentil seedlings were homogenized with $2.5 \mathrm{~mL} 5 \%$ perchloric acid (PCA) using a mortar and pestle and then centrifuged at $11,000 \times g$ for $10 \mathrm{~min}$. The supernatant was mixed with charcoal and centrifuged again. The clarified supernatant was neutralized using saturated $\mathrm{Na}_{2} \mathrm{CO}_{3}$ and used for the estimation of methylglyoxal (MG) through the addition of $\mathrm{NaH}_{2} \mathrm{PO}_{4}$ (sodium hydrogen phosphate) and N-acetyl-L-cysteine. The absorbance was measured at $288 \mathrm{~nm}$ for MG determination.

\subsection{Statistical Analysis}

XLSTAT v.2020 software (Addinsoft, Paris, France) using Fisher's least significant difference (LSD) at $5 \%$ probability $(p \leq 0.05)$ used to evaluate the comparable mean difference of three replications and the analysis of variance (ANOVA). 


\section{Results}

3.1. L-Glu Improved the Phenotypic Appearance and Survival of Lentil Seedlings Grown under Salinity Stress

The effect of salt stress and the role of L-Glu in mitigating salt-induced damage in lentil seedlings were investigated by initially exposing the seedlings to $110 \mathrm{mM}$ salt stress with or without different doses of L-Glu ranging from 0.3 to $20 \mathrm{mM}$ (Figure S1a-d). We ultimately selected $10 \mathrm{mM}$ L-Glu for further work, as this dose gave a better recovery of the plant phenotype following $110 \mathrm{mM} \mathrm{NaCl}$ stress (Figure S1a-d). The dose of salt stress was selected from a range of $75-150 \mathrm{mM} \mathrm{NaCl}$ (Figure S2a-d). The highest dose of $\mathrm{NaCl}$ $(150 \mathrm{mM})$ showed lower survival than the lower doses in response to L-Glu pretreatment (Figure S2d). We also checked the effects of other amino acids in the same concentration of L-Glu (10 mM), such as L-glutamine, L-glycine, L-asparagine, L-methionine, and L-cysteine, under salt-stress conditions, but L-Glu pretreatment gave a better phenotypic appearance and survival performance compared to the other amino acids (Figure S3a,b). The stressed plants became stunted and wilted and some leaves turned yellowish in color, but the plants pretreated with L-Glu were healthier and greener as they recovered from the imposed salt stress (Figure 1a,b). As the recovery period progressed, more seedlings failed to recover from the salt stress in the absence of the L-Glu treatment. Approximately $97 \%$ of the seedlings survived the saline treatment when pretreated with L-Glu vs. approximately $15 \%$ of plants that survived when exposed to $110 \mathrm{mM}$ salt without L-Glu pretreatment (Figure 1c).
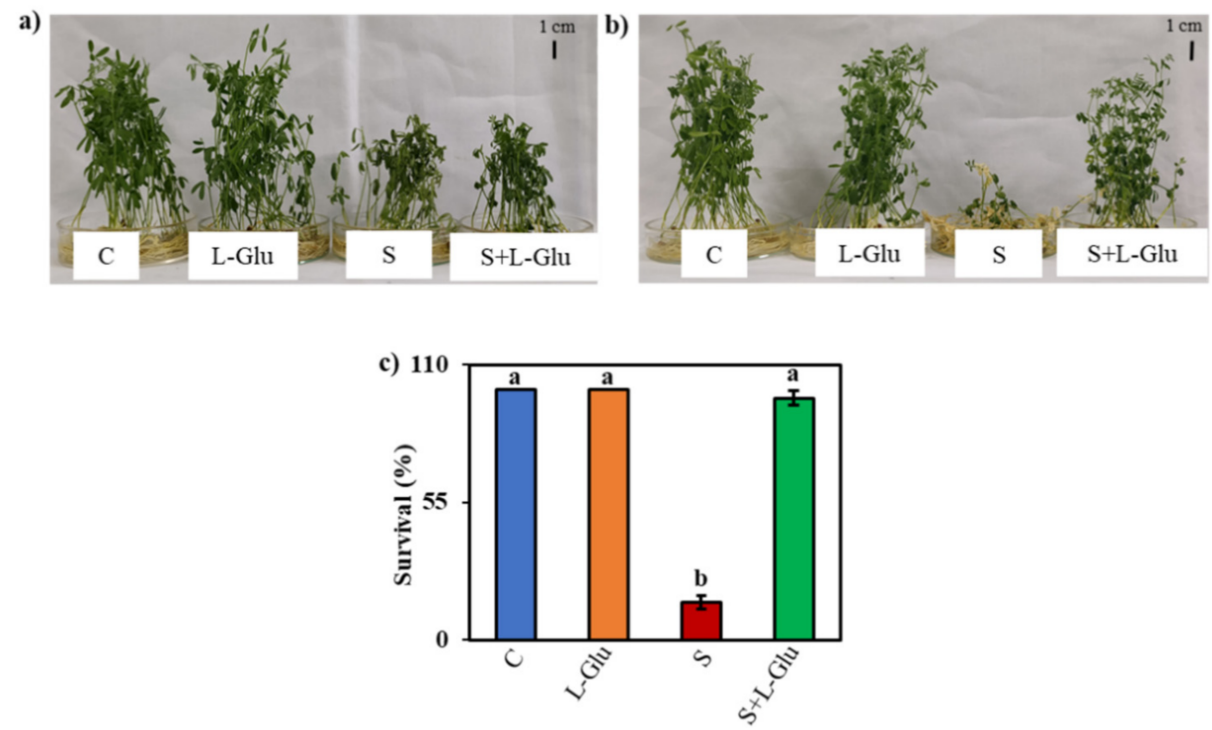

Figure 1. Effect of L-Glutamic acid (L-Glu) on (a) the phenotypic appearance of lentil seedlings after 2 days of recovery, (b) the phenotypic appearance of lentil seedlings after 7 days of recovery and (c) the survival percentage of lentil seedlings after 7 days of recovery. The treatments were control (C), $10 \mathrm{mM}$ L-Glu, $110 \mathrm{mM} \mathrm{NaCl}$ (S) and $110 \mathrm{mM} \mathrm{NaCl}+10 \mathrm{mM}$ L-Glutamic acid (S+ L-Glu). The above mean $( \pm \mathrm{SE})$ was calculated from three replications. Values of different letters indicate statistically significant differences at $p \leq 0.05$ (Fisher's LSD test).

3.2. L-Glutamic Acid Improved the Growth and Water Content and Reduced the Proline Content Of Lentil Plants Exposed to Salt Stress

Salt stress has many detrimental effects on plants; therefore, we evaluated the protective role of L-Glu pretreatment by measuring growth and water status parameters, such as SFW, SDW, WC, and Pro content (Table 1). The SFW and SDW of salt-stressed plants decreased by $50 \%$ and $23 \%$, respectively, in comparison with the control. Conversely, L-Glu pretreatment elevated the SFW and SDW by $38 \%$ and $7 \%$, respectively, compared with salt-stressed seedlings without L-Glu pretreatment (Table 1). The WC declined by $11 \%$ 
under salt-stress conditions, but it was increased by $8 \%$ after the application of L-Glu (Table 1). The Pro content increased by 374\% compared to unstressed control plants in response to the $110 \mathrm{mM}$ salt treatment, but pretreatment with L-Glu reduced the amount of proline (by $42 \%$ ) in plants under salinity stress compared to salt-stressed plants (Table 1).

Table 1. Effect of L-Glutamic acid (L-Glu) on shoot fresh weight (SFW), shoot dry weight (SDW), water content (WC) and proline content (Pro) of lentil seedlings. The mean ( \pm SE) was calculated from three replications. Values of different letters indicate statistically significant differences at $p \leq 0.05$ (Fisher's LSD test).

\begin{tabular}{ccccc}
\hline Treatments & SFW (mg shoot $\left.{ }^{-1}\right)$ & SDW $\left(\mathbf{m g ~ s h o o t}^{-1}\right)$ & WC $(\mathbf{\%})$ & Pro $^{\left(\mu \mathbf{m o l} \mathbf{g}^{-1} \mathbf{D W}\right)}$ \\
\hline C & $70.5 \pm 2.3 \mathrm{a}$ & $12.1 \pm 0.26 \mathrm{a}$ & $82.8 \pm 0.5 \mathrm{~b}$ & $24.5 \pm 3.7 \mathrm{c}$ \\
L-Glu & $71.1 \pm 1.8 \mathrm{a}$ & $11.8 \pm 0.15 \mathrm{a}$ & $83.4 \pm 0.5 \mathrm{a}$ & $28.4 \pm 2.3 \mathrm{c}$ \\
S & $35.3 \pm 1.4 \mathrm{c}$ & $9.4 \pm 0.03 \mathrm{c}$ & $73.4 \pm 1.0 \mathrm{~d}$ & $116.3 \pm 4.4 \mathrm{a}$ \\
S + L-Glu & $48.6 \pm 1.9 \mathrm{~b}$ & $9.97 \pm 0.3 \mathrm{~b}$ & $79.5 \pm 0.3 \mathrm{c}$ & $67.7 \pm 0.3 \mathrm{~b}$ \\
\hline
\end{tabular}

\subsection{L-Glu Protected Photosynthetic Pigments under Saline Stress}

Measurements of photosynthetic pigments, such as Chl a, Chl b, Chl (a + b), and Car, in leaves of lentil plants under salt stress revealed declines from the unstressed values $\mathrm{Chl}$ a $(1.52 \mathrm{mg}) \mathrm{Chl} b(0.34 \mathrm{mg}), \mathrm{Chl}(\mathrm{a}+\mathrm{b})(1.9 \mathrm{mg})$ and $\mathrm{Car}(0.17 \mathrm{mg})$ of $57 \%, 58 \%, 57 \%$, and $76 \%$, respectively (Figure $2 \mathrm{a}-\mathrm{d}$ ). However, L-Glu application alleviated salt stress since pigment composition in S + L-Glu was 186\%,89\%, 168\% and 336\% of that of the control for $\mathrm{Chl} \mathrm{a,Chl} \mathrm{b,} \mathrm{Chl}(\mathrm{a}+\mathrm{b})$ and Car, respectively (Figure $2 \mathrm{a}-\mathrm{d})$.
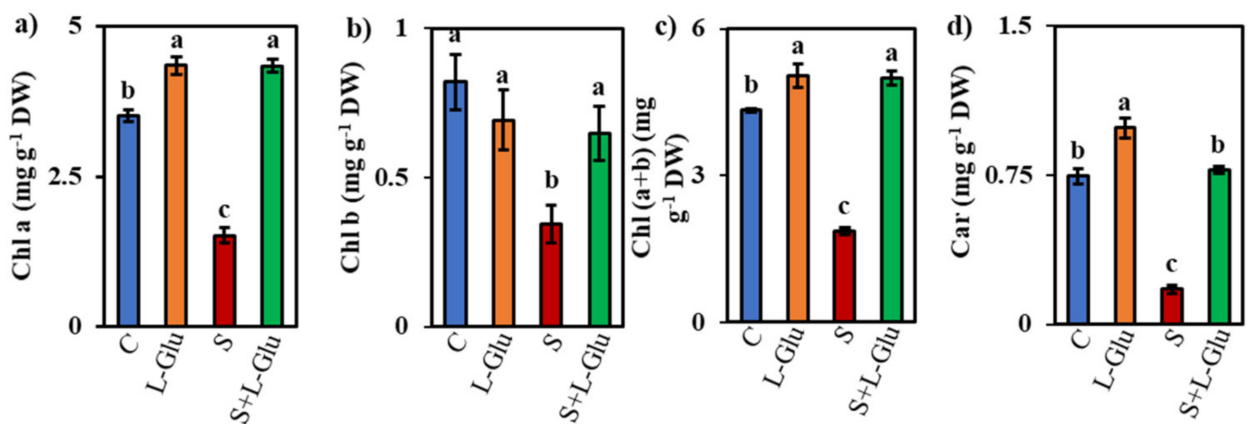

Figure 2. Effect of L-Glutamic acid (L-Glu) on photosynthetic pigment (a) Chlorophyll a (Chl a), (b) Chlorophyll b (Chl b), (c) Chlorophyll $(\mathrm{a}+\mathrm{b})(\mathrm{Chl}(\mathrm{a}+\mathrm{b}))$ and $(\mathrm{d})$ the Carotenoid (Car) content of lentil seedlings under salt stress and subsequent recovery. The above mean $( \pm \mathrm{SE})$ was calculated from three replications. Values of different letters indicate statistically significant differences at $p \leq 0.05$ (Fisher's LSD test).

\subsection{L-Glu Decreased Oxidative Damage in Lentil Plants}

Lipid peroxidation is a major sign of oxidative damage in plants and can be measured by assessing the MDA content. Salt stress increased the MDA content by $164 \%$ compared with unstressed control plants, but L-Glu-pretreatment suppressed this salt-stress-induced increase in MDA content by 65\% (Figure 3a). Compared with the unstressed controls, the content of other aldehydes, $\mathrm{H}_{2} \mathrm{O}_{2}$ content, and EL and MG content increased by $229 \%$, $51 \%, 434 \%$, and $114 \%$, respectively, under salt stress (Figure $3 \mathrm{~b}-\mathrm{e}$ ). Conversely, in L-Glupretreated seedlings, these indicators declined by $68 \%, 22 \%, 53 \%$, and $40 \%$, respectively, compared with salt-stressed seedlings (Figure $3 b-e$ ). 

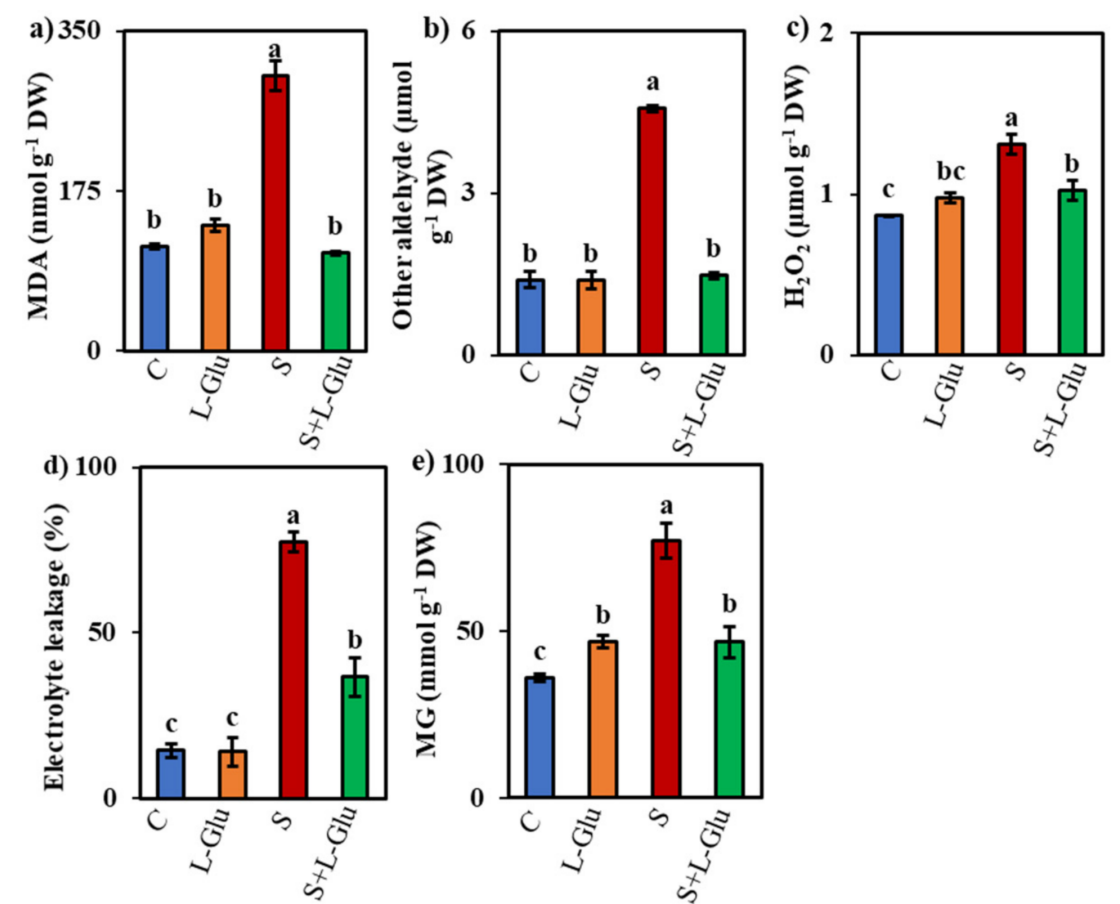

Figure 3. Effect of L-Glutamic acid (L-Glu) on the (a) malonaldehyde (MDA), (b) other aldehyde, (c) hydrogen peroxide $\left(\mathrm{H}_{2} \mathrm{O}_{2}\right)$, (d) electrolyte leakage and (e) methylglyoxal (MG) content of lentil seedlings under salt stress and recovery conditions. The above mean $( \pm \mathrm{SD})$ was calculated from three replications. Values of different letters indicate statistically significant differences at $p \leq 0.05$ (Fisher's LSD test).

\subsection{L-Glu Impact on Non-Enzymatic and Enzymatic Antioxidants under Salinity Stress}

We investigated the effect of L-Glu on non-enzymatic and enzymatic antioxidants in response to salt stress by measuring the non-enzymatic antioxidant content ((AsA, GSH, and GSSG) and GSH/GSSG ratio) and enzyme activities (CAT, APX, MDHAR, DHAR, GR, GST, and GPX). The AsA content increased in the L-Glu-pretreated seedlings under both control and salt-stress conditions by $42 \%$ and $123 \%$, respectively, when compared to untreated control and salt-stressed seedlings, respectively (Figure 4a). However, AsA contents were $70 \%$ lower in plants exposed to $110 \mathrm{mM}$ salt than in the unstressed controls (Figure 4a). Conversely, the GSH and GSSG contents were enhanced by $305 \%$ and $353 \%$, respectively, whereas the GSH/GSSG ratio was reduced by $11 \%$ under the salt-stress condition compared with the unstressed control (Figure $4 \mathrm{~b}-\mathrm{d}$ ). L-Glu pretreatment reduced the GSH and GSSG content by $55 \%$ and $73 \%$, respectively, compared with untreated saltstressed seedlings, whereas L-Glu pretreatment increased the GSH/GSSG ratio by $74 \%$ under salinity stress compared with the untreated salt-stressed seedlings (Figure $4 b-d$ ).

Salt stress decreased the activity of CAT and APX by $71 \%$ and $41 \%$, respectively, compared to the unstressed controls (Figure 4e,f). However, L-Glu pretreatment enhanced the CAT and APX enzyme activity by $232 \%$ and $57 \%$ compared with the untreated salt-stressed seedlings (Figure 4e,f). MDHAR activity was increased by $17 \%$ and $41 \%$ in L-Glu-treated seedlings under control and salt-stress conditions, respectively, when compared with the control and salt-stress conditions in the absence of L-Glu pretreatment (Figure 4g). The DHAR activity increased (by $47 \%$ ) under salinity stress, but L-Glu pretreatment suppressed this increase by $39 \%$ under the salt-stress condition (Figure $4 \mathrm{~h}$ ).

The activities of GR and GPX increased by $83 \%$ and $162 \%$, respectively, in salt-stressed seedlings compared with the unstressed control (Figure $4 \mathrm{i}, \mathrm{j}$ ). However, L-Glu pretreatment suppressed this increase by $49 \%$ and $56 \%$, respectively, compared with the untreated saltstressed plants (Figure $4 \mathrm{i}, \mathrm{j}$ ). By contrast, the GST activity increased by $36 \%$ in response to L-Glu pretreatment compared to the untreated salt-stressed plants (Figure 4k). 

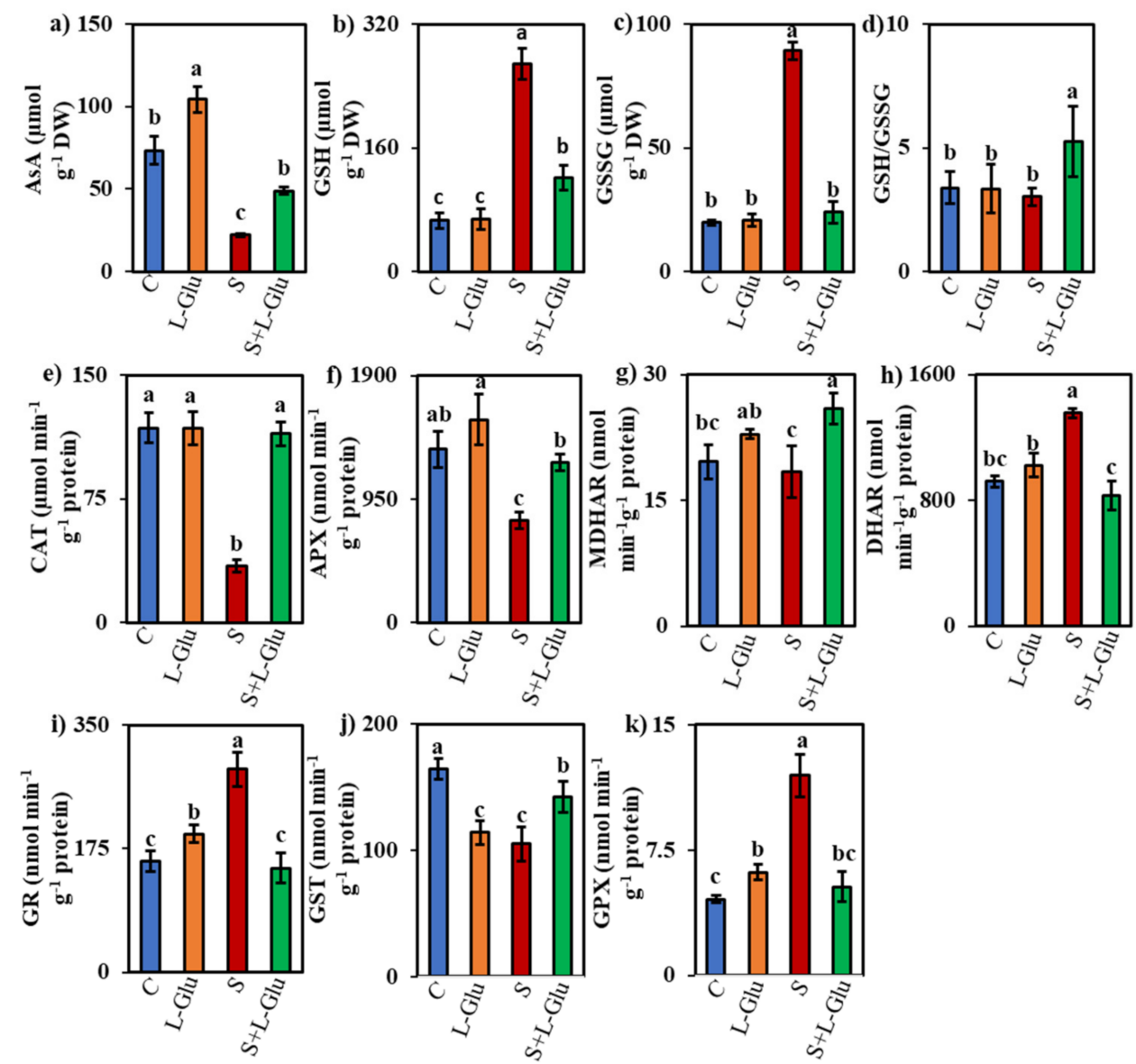

Figure 4. Effect of L-Glutamic acid (L-Glu) on the content of non-enzymatic antioxidants (a) ascorbate (AsA), (b) reduced glutathione (GSH), (c) oxidized glutathione (GSSG) and (d) GSH/GSSG; activity of enzymatic antioxidants (e) catalase (CAT), (f) ascorbate peroxidase (APX), (g) monodehydroascorbate reductase (MDHAR), (h) dehydroascorbate reductase (DHAR), (i) glutathione reductase (GR), (j) glutathione $S$-transferase (GST) and (k) glutathione peroxidase (GPX) of lentil seedlings under salt stress and recovery conditions. The above mean $( \pm \mathrm{SE})$ was calculated from three replications. Values of different letters indicate statistically significant differences at $p \leq 0.05$ (Fisher's LSD test).

\subsection{L-Glu Regulated Ion Homeostasis during Salt Stress}

We further examined the role of L-Glu on ion homeostasis in response to salt stress by determining the $\mathrm{Na}^{+}, \mathrm{K}^{+}, \mathrm{Ca}^{2+}$, and $\mathrm{Mg}^{2+}$ contents in the leaves, shoots, and roots of lentil seedlings. L-Glu pretreatment resulted in lower plant leaf, shoot, and root levels of $\mathrm{Na}^{+}\left(33 \%, 32 \%\right.$, and $33 \%$ lower, respectively) and higher $\mathrm{K}^{+}$levels $(3 \%, 71 \%$, and $67 \%$, respectively) compared to untreated salt-stressed plants (Table 2). However, the saltstressed seedlings showed markedly higher leaf, shoot, and root $\mathrm{Na}^{+}$contents and lower $\mathrm{K}^{+}$contents compared with the unstressed control plants (Table 2). The leaf, shoot and root $\mathrm{Na}^{+} / \mathrm{K}^{+}$ratios were also markedly higher in the salt-stressed seedlings than in the controls. Pretreatment with L-Glu decreased the ratios of $\mathrm{Na}^{+} / \mathrm{K}^{+}$by $35 \%, 61 \%$, and $60 \%$ for the leaves, shoots, and roots, respectively, when compared with the untreated salt-stressed seedlings (Table 2). Salt stress also decreased the leaf, shoot, and root contents of $\mathrm{Ca}^{2+}$ (by $71 \%, 80 \%$, and $56 \%$, respectively) and the shoot and root contents of $\mathrm{Mg}^{2+}$ (by $58 \%$ and $98 \%$, respectively) compared with the unstressed controls (Figure S4a-f). L-Glu pretreatment suppressed the decline in leaf, shoot, and root $\mathrm{Ca}^{2+}$ and $\mathrm{Mg}^{2+}$ levels in response to salt stress (Figure S4a-f). 
Table 2. Effect of L-Glutamic acid (L-Glu) on the level of leaf, shoot and root $\mathrm{Na}^{+}, \mathrm{K}^{+}$and $\mathrm{Na}^{+} / \mathrm{K}^{+}$ ratio in lentil seedlings under salt stress and recovery conditions. The above mean $( \pm \mathrm{SE})$ was calculated from three replications. Values of different letters indicate statistically significant differences at $p \leq 0.05$ (Fisher's LSD test).

\begin{tabular}{|c|c|c|c|c|}
\hline & Treatment & Leaf & Shoot & Root \\
\hline $\begin{array}{c}\mathrm{Na}^{+} \text {content } \\
\left(\mu \mathrm{mol} \mathrm{g}{ }^{-1} \mathrm{DW}\right)\end{array}$ & $\begin{array}{c}\text { C } \\
\text { L-Glu } \\
\text { S } \\
\text { S + L-Glu }\end{array}$ & $\begin{array}{c}9 \pm 0.8 c \\
21 \pm 0.6 c \\
1000 \pm 28 a \\
671 \pm 26 b\end{array}$ & $\begin{array}{c}21 \pm 0.6 \mathrm{c} \\
31 \pm 1 \mathrm{c} \\
1018 \pm 22 \mathrm{a} \\
691 \pm 35 \mathrm{~b}\end{array}$ & $\begin{array}{c}20 \pm 11 d \\
145 \pm 7 c \\
1096 \pm 14 a \\
736 \pm 45 b\end{array}$ \\
\hline $\begin{array}{c}\mathrm{K}^{+} \text {content } \\
\left(\mu \mathrm{mol} \mathrm{g}{ }^{-1} \mathrm{DW}\right)\end{array}$ & $\begin{array}{c}\text { C } \\
\text { L-Glu } \\
\text { S } \\
\text { S + L-Glu }\end{array}$ & $\begin{array}{c}315 \pm 13 b \\
342 \pm 25 b \\
524 \pm 6 a \\
539 \pm 7 a\end{array}$ & $\begin{array}{c}505 \pm 11 a \\
479 \pm 9 a \\
211 \pm 14 c \\
361 \pm 8 b\end{array}$ & $\begin{array}{l}377 \pm 17 b \\
489 \pm 13 \mathrm{a} \\
206 \pm 11 \mathrm{c} \\
344 \pm 12 \mathrm{~b}\end{array}$ \\
\hline $\mathrm{Na}^{+} / \mathrm{K}^{+}$ratio & $\begin{array}{c}\text { C } \\
\text { L-Glu } \\
\text { S } \\
\text { S + L-Glu }\end{array}$ & $\begin{aligned} 0.03 & \pm 0.004 \mathrm{c} \\
0.06 & \pm 0.004 \mathrm{c} \\
1.9 & \pm 0.04 \mathrm{a} \\
1.3 & \pm 0.05 \mathrm{~b}\end{aligned}$ & $\begin{array}{c}0.04 \pm 0.002 \mathrm{c} \\
0.07 \pm 0.001 \mathrm{c} \\
4.9 \pm 0.4 \mathrm{a} \\
1.9 \pm 0.1 \mathrm{~b}\end{array}$ & $\begin{array}{c}0.06 \pm 0.03 \mathrm{c} \\
0.3 \pm 0.02 \mathrm{c} \\
5.4 \pm 0.3 \mathrm{a} \\
2.2 \pm 0.07 \mathrm{~b}\end{array}$ \\
\hline
\end{tabular}

\subsection{Correlation Analysis}

We used correlation analysis to identify important factors for salt tolerance in lentil plants. The accumulation of $\mathrm{Na}^{+}$was positively correlated with the oxidative damage markers (MDA, $\mathrm{H}_{2} \mathrm{O}_{2}$, EL, MG, and other aldehydes) but was negatively correlated with growth parameters, survivability, and photosynthetic pigment levels (Figure S5). Among the components of the antioxidant defense pathway, CAT, APX, and AsA showed a negative correlation with the oxidative damage markers (Figure S5).

\section{Discussion}

Soil salinity severely disturbs the plant morphological, physiological, biochemical, and metabolic processes, including enzymatic activity, photosynthesis, and cell membrane integrity [46]. These disturbances in vital processes in plants under salt stress result in crop yield decreases and pose a serious threat to global food security. Thus, mitigating salt-induced damage in plants is an important research objective. Scientists have already started to use different strategies, including the use of exogenous chemicals, to mitigate saltinduced damage in different plants [47,48], but the search continues for low-cost chemicals that are both effective and ecofriendly. The results presented here indicate that L-Glu could play an important role as a low-cost chemical capable of alleviating the adverse effects of salt stress in lentil seedlings. L-Glu, as a protein amino acid, plays an important role in the growth and development of plants and in adaptation to stress [27,28]. However, the benefits of the exogenous application of L-Glu in enhancing salt stress tolerance have not been adequately explored.

In our investigation, we first determined whether L-Glu application could enhance the survival of lentil seedlings after 7 days of recovery from salt stress (Figure 1b,c). Most of the seedlings withered and failed to survive during recovery from salt stress. However, the L-Glu pretreatment enhanced the survival rate by $97 \%$ (Figure 1c), indicating that L-Glu is able to aid in overcoming the detrimental effects of salt stress. Compared to other amino acids, L-Glu was more effective at inducing salt tolerance (Figure 3a,b and Figure S2c). One clear response to salt stress was an arrest of plant growth, as indicated by declines in biomass production (shoot fresh weight and dry weight) (Table 1); these effects have been attributed to osmotic shock [1]. Our findings agreed with a previous report by Hossain et al. $[49,50]$, who also noted a salt stress-induced growth reduction and lower survival rate in lentil seedlings. However, the pretreatment with L-Glu was able to mitigate the salt-induced losses in the shoot fresh weight and dry weight of lentil seedlings, suggesting that L-Glu reduces the effect of osmotic stress (Table 1). Sadak et al. [51] reported 
that a mixture of amino acids, which included L-Glu, enhanced biomass under salt-stress conditions, and they suggested a potential role for amino acids as biostimulants.

When under salt stress, plants may sense perturbations in water status and respond by synthesizing different osmolytes, most notably amino acids such as Pro or carbohydrates and their derivatives, which act as osmoprotectants $[52,53]$. In the present study, stressed plants accumulated more Pro in proportion to their water content (Table 1). L-Glu pretreatment reduced the accumulation of Pro in response to salt stress (Table 1), indicating that the L-Glu-pretreated seedlings experienced a lesser worsening of water status, as revealed by their higher water content compared to the salt-stressed plants (Table 1).

The photosynthetic pigment content is another important parameter that is directly correlated with plant growth and biomass [54]. Salt stress markedly reduced the levels of chlorophylls (Chl a, Chl b, Chl (a + b)) and Car (Figure 2a-d), in agreement with the findings of Qados [55], Rahman et al. [56], and Pandey and Sengar [57], who reported photosynthetic pigment damage in bean, acacia, and lentil seedlings under salt stress. The reduction in Chl $(\mathrm{a}+\mathrm{b})$ and Car content indicates that lentil seedlings failed to improve photosynthetic efficiency in response to salt stress, with further effects on plant growth and lower biomass. However, L-Glu enhanced the contents of $\mathrm{Chl} \mathrm{a}, \mathrm{Chl} \mathrm{b}, \mathrm{Chl}(\mathrm{a}+\mathrm{b})$ and $\mathrm{Car}$ in both salt-stressed and unstressed seedlings (Figure $2 \mathrm{a}-\mathrm{d}$ ), indicating a direct involvement of L-Glu in light energy capturing and cooperation among the different pigments to increase photosynthetic performance. This result was consistent with the findings of La et al. [27], who demonstrated a Glu-mediated augmentation of total Chl and Car contents in radish seedlings under drought stress conditions.

Like other abiotic stresses, salt stress elevates ROS production and causes instability in the antioxidant defense system that, in turn, results in severe oxidative damage in plants [58]. In our study, we measured the content of MDA, other aldehydes, and $\mathrm{H}_{2} \mathrm{O}_{2}$, as well as EL and MG, to understand the level of oxidative damage in salt-stressed lentil plants (Figure 3a-e). We found increases in all these parameters in response to salt stress (Figure 3a-e), indicating severe oxidative damage. Our results agree with previous findings reporting increased ROS load in plants growing in saline environments [59-61]. Pretreatment with L-Glu rescued the lentil seedlings from ROS-induced oxidative stress by lowering the MDA and $\mathrm{H}_{2} \mathrm{O}_{2}$ content (Figure $3 \mathrm{a}, \mathrm{c}$ ) while also reducing the extent of EL (Figure 3d). These results are in agreement with previous work showing that L-Glu application decreases ROS accumulation under drought stress [27]. As a dicarbonyl compound, MG causes the denaturation of DNA, RNA, protein, and lipids by increasing ROS accumulation and inhibiting the activity of antioxidants [62,63]. MG showed an overaccumulation in salt-stressed lentils (Figure 3e), in agreement with previous reports of high MG accumulations in wheat, mustard, and mung bean seedlings under salt stress [64-66]. However, L-Glu pretreatment suppressed this MG content accumulation in response to salt stress (Figure 3e), suggesting that L-Glu pretreatment reduced ROS accumulation and oxidative damage by modulating the components of the antioxidant defense system.

Stress tolerance can be achieved by efficient ROS detoxification, especially through the action of enzymatic and non-enzymatic antioxidants, which increased plant survival under stress conditions by protecting plants from oxidative damage [67,68]. AsA and GSH are two vital non-enzymatic components of the plant antioxidant defense system, where they work as promoters of redox buffering and as suppliers of electrons to APX and GPX enzymes [69-71]. AsA is regenerated by the enzyme pair MDHAR and DHAR. Conversely, GR helps to maintain the GSH pool by regenerating GSH from GSSG by the activity of GST following glutathione oxidation and by managing the redox balance of plant by maintaining a stable GSH/GSSG ratio [72]. In the present study, we observed lower CAT and APX activities and AsA contents in stressed lentil plants (Figure 4a,e,f). This may explain the higher $\mathrm{H}_{2} \mathrm{O}_{2}$ accumulation observed under salt stress, as CAT and APX activities convert $\mathrm{H}_{2} \mathrm{O}_{2}$ to water. Tepe and Aydemir [73] also reported a downregulation of CAT and APX in lentils under salt stress, in line with our findings. L-Glu application prevented the suppression of CAT and APX activities under salt stress (Figure 4e,f), suggesting that 
L-Glu application can modulate both the enzymatic and non-enzymatic components of the antioxidant defense pathway under stress conditions. La et al. [27] reported an increase in CAT activity under drought stress following L-Glu application.

In our study, we observed increased activities of DHAR, GR, and GPX, but no change in MDHAR and GST activities under salt stress (Figure $4 \mathrm{~g}-\mathrm{k}$ ), indicating that seedlings acclimated to the stress conditions by reducing $\mathrm{H}_{2} \mathrm{O}_{2}$ through GPX and by increasing AsA and GSH recycling through DHAR and GR. Different responses of the components of the antioxidant defense pathway have also been reported in rice [25], maize [74], and soybean [75]. In our study, L-Glu application decreased DHAR, GPX, and GR activities and increased the MDHAR and GST activities in the salt-stressed seedlings (Figure 4g-k). We observed different responses of the components of the antioxidant defense pathway in lentil seedlings under salt-stress conditions, suggesting a disturbance in the maintenance of ROS homeostasis. The response of the antioxidant defense pathway varies with the dose, duration, and type of stress, as well as the age and genotype of the plant species and other experimental conditions [3]. Upregulation of one or two components, instead of the full complement of the pathway, may enhance stress tolerance in plants [3]. Current evidence suggests that increasing CAT activity and AsA content are essential for salt and copper stress tolerance in lentil seedlings $[34,49,50]$. We observed a strong negative correlation between oxidative damage markers and CAT, APX and AsA activities (Figure S5), suggesting that increased activities of CAT, APX and AsA mediated by L-Glu play a critical role in reducing the oxidative damage under salt stress, thereby contributing to the better survival of seedlings under such conditions.

Salt tolerance in plants largely depends on the accumulation and translocation of toxic $\mathrm{Na}^{+}$in different parts of plants $[9,76]$. Salt stress also disrupts nutrient homeostasis by interrupting the uptake and transport of $\mathrm{K}^{+}, \mathrm{Ca}^{2+}$, and $\mathrm{Mg}^{2+}[49,77]$. Maintaining nutrient homeostasis and the $\mathrm{Na}^{+} / \mathrm{K}^{+}$ratio is crucial for plant growth and survivability in saline environments [78,79]. In this study, salt-stressed seedlings had higher $\mathrm{Na}^{+}$levels and $\mathrm{Na}^{+} / \mathrm{K}^{+}$ratios, and lower $\mathrm{K}^{+}, \mathrm{Ca}^{2+}$, and $\mathrm{Mg}^{2+}$ levels, indicating that salt stress disturbed ion homeostasis, thereby resulting in lower biomass production (Table 2 and Figure S4a-f). Correlation analysis suggested that growth parameters and photosynthetic pigments were strongly negatively correlated with $\mathrm{Na}^{+}$accumulation (Figure S5). Singh et al. [80] and Hossain et al. [50] also reported higher accumulations of $\mathrm{Na}^{+}$and higher $\mathrm{Na}^{+} / \mathrm{K}^{+}$ratios, as well as lower $\mathrm{K}^{+}, \mathrm{Ca}^{2+}$, and $\mathrm{Mg}^{2+}$ levels in lentil seedlings under salt stress. However, L-Glu pretreatment reduced the $\mathrm{Na}^{+}$accumulation and restored the $\mathrm{Na}^{+} / \mathrm{K}^{+}$ratio while also increasing the $\mathrm{K}^{+}, \mathrm{Ca}^{2+}$ and $\mathrm{Mg}^{2+}$ contents in lentil seedlings (Table 2 and Figure S4a-f). Exogenous application of amino acids reduced the $\mathrm{Na}^{+}$accumulation in leaves of faba bean [51], in agreement with our results. These responses could explain the reduction in photosynthetic pigment damage and the better growth of the L-Glu-treated seedlings under salt stress. Exogenous chemicals, such as acetate, calcium chloride, glutathione, polyamines, and amino acids, are now well established as having the potential to maintain nutrient homeostasis in plants under salt stress, thereby enhancing salt tolerance $[50,51,77,81,82]$.

\section{Conclusions}

Salt stress inhibited the growth and lowered the survival of lentil seedlings during recovery from salt stress. The application of L-Glu negated the salt-induced damage by inducing various biochemical and physiological responses, including (a) the reduction of $\mathrm{Na}^{+}$accumulation and maintenance of ion homeostasis, (b) the protection of photosynthetic pigments, and (c) the reduction of oxidative stress through increased action of antioxidant defense systems (CAT, AsA, and APX). These findings imply that the pretreatment of saltstressed plants with L-Glu could be a cost-effective method for reducing the detrimental effects of salt stress on crop growth. However, this study evaluated the effects of short-term salinity on lentil seedlings cultured in petri plates. Therefore, further investigation is required to evaluate whether L-Glu can mitigate the damages in lentil seedlings grown on salt-affected land. 
Supplementary Materials: The following are available online at https:/ / www.mdpi.com/article/10 $.3390 /$ biom11040587/s1, Figure S1: Effect of different doses of L-Glutamic acid on lentil seedlings in response to salt stress and recovery condition, Figure S2: Effect of different doses of $\mathrm{NaCl}$ on lentil seedlings pretreatment with $10 \mathrm{mM}$ L-Glu after 7 days of recovery condition, Figure S3: Effect of another amino acid in lentil seedlings under $110 \mathrm{mM} \mathrm{NaCl}$ stress and recovery condition, Figure S4: Effect of L-Glutamic acid on the level of (a) leaf $\mathrm{Ca}^{2+}$, (b) shoot $\mathrm{Ca}^{2+}$, (c) root $\mathrm{Ca}^{2+}$, (d) leaf $\mathrm{Mg}^{2+}$, (e) shoot $\mathrm{Mg}^{2+}$ and (f) root $\mathrm{Mg}^{2+}$ in lentil seedlings under salt stress and recovery condition, Figure S5: Correlation analysis between $\mathrm{L}-\mathrm{Glu}$ and $\mathrm{NaCl}$ application and different growth attributes of lentil seedlings.

Author Contributions: J.F. performed the experiments and prepared the manuscript; M.S.H. actively participated in executing the experiment, analyzed the data and edited the manuscript; M.F. conceived, designed, and monitored the experiment. All authors have read and agreed to the published version of the manuscript.

Funding: This research received no external funding.

Acknowledgments: We thank Mirza Hasanuzzaman for improving the manuscript.

Conflicts of Interest: The authors declare no conflict of interest.

\section{References}

1. Munns, R.; Tester, M. Mechanisms of salinity tolerance. Annu. Rev. Plant Biol. 2008, 59, 651-681. [CrossRef]

2. Farooq, M.; Gogoi, N.; Hussain, M.; Barthakur, S.; Paul, S.; Bharadwaj, N.; Migdadi, H.M.; Alghamdi, S.S.; Siddique, K.H. Effects, tolerance mechanisms and management of salt stress in grain legumes. Plant Physiol. Biochem. 2017, 118, 199-217. [CrossRef]

3. Abogadallah, G.M. Insights into the significance of antioxidative defense under salt stress. Plant Signal. Behav. 2010, 5, 369-374. [CrossRef]

4. Matthees, H.L.; Thom, M.D.; Gesch, R.W.; Forcella, F. Salinity tolerance of germinating alternative oilseeds. Ind. Crops Prod. 2018, 113, 358-367. [CrossRef]

5. Hasanuzzaman, M.; Hossain, M.A.; da Silva, J.A.T.; Fujita, M. Plant response and tolerance to abiotic oxidative stress: Antioxidant defense is a key factor. In Crop Stress and Its Management: Perspectives and Strategies; Springer: Dordrecht, The Netherlands, 2012; pp. 261-315.

6. Parvin, K.; Hasanuzzaman, M.; Bhuyan, M.H.M.; Nahar, K.; Mohsin, S.M.; Fujita, M. Comparative physiological and biochemical changes in tomato (Solanum lycopersicum L.) under salt stress and recovery: Role of antioxidant defense and glyoxalase systems. Antioxidants 2019, 8, 350. [CrossRef] [PubMed]

7. Dawood, M.G.; Taie, H.A.A.; Nassar, R.M.A.; Abdelhamid, M.T.; Schmidhalter, U. The changes induced in the physiological, biochemical and anatomical characteristics of Vicia faba by the exogenous application of proline under seawater stress. S. Afr. J. Bot. 2014, 93, 54-63. [CrossRef]

8. Ahmad, P.; Jaleel, C.A.; Salem, M.A.; Nabi, G.; Sharma, S. Roles of enzymatic and nonenzymatic antioxidants in plants during abiotic stress. Crit. Rev. Biotechnol. 2010, 30, 161-175. [CrossRef]

9. Gupta, B.; Huang, B. Mechanism of salinity tolerance in plants: Physiological, biochemical, and molecular characterization. Int. J. Genom. 2014, 2014, 701596. [CrossRef] [PubMed]

10. Soares, C.; Carvalho, M.E.; Azevedo, R.A.; Fidalgo, F. Plants facing oxidative challenges-A little help from the antioxidant networks. Environ. Exp. Bot. 2019, 161, 4-25. [CrossRef]

11. Sevilla, F.; Jiménez, A.; Lázaro, J.J. What do the plant mitochondrial antioxidant and redox systems have to say under salinity, drought, and extreme temperature? In Reactive Oxygen Species and Oxidative Damage in Plants under Stress; Springer: Cham, Switzerland, 2015; pp. 23-55.

12. Negrão, S.; Schmöckel, S.M.; Tester, M. Evaluating physiological responses of plants to salinity stress. Ann. Bot. 2017, 119, 1-11. [CrossRef] [PubMed]

13. Lin, K.H.; Kuo, W.S.; Chiang, C.M.; Hsiung, T.C.; Chiang, M.C.; Lo, H.F. Study of sponge gourd ascorbate peroxidase and winter squash superoxide dismutase under respective flooding and chilling stresses. Sci. Hortic. 2013, 162, 333-340. [CrossRef]

14. Ohama, N.; Sato, H.; Shinozaki, K.; Yamaguchi-Shinozaki, K. Transcriptional regulatory network of plant heat stress response. Trends Plant Sci. 2017, 22, 53-65. [CrossRef] [PubMed]

15. Li, Q.; Yu, H.M.; Meng, X.F.; Lin, J.S.; Li, Y.J.; Hou, B.K. Ectopic expression of glycosyltransferase UGT 76E11 increases flavonoid accumulation and enhances abiotic stress tolerance in Arabidopsis. Plant Biol. 2018, 20, 10-19. [CrossRef] [PubMed]

16. Ma, X.; Chen, C.; Yang, M.; Dong, X.; Lv, W.; Meng, Q. Cold-regulated protein (SICOR413IM1) confers chilling stress tolerance in tomato plants. Plant Physiol. Biochem. 2018, 124, 29-39. [CrossRef] [PubMed]

17. Savvides, A.; Ali, S.; Tester, M.; Fotopoulos, V. Chemical priming of plants against multiple abiotic stresses: Mission possible? Trend. Plant Sci. 2016, 21, 329-340. [CrossRef] [PubMed]

18. Nguyen, H.C.; Lin, K.H.; Ho, S.L.; Chiang, C.M.; Yang, C.M. Enhancing the abiotic stress tolerance of plants: From chemical treatment to biotechnological approaches. Physiol. Plant. 2018, 164, 452-466. [CrossRef] 
19. Irani, S.; Todd, C.D. Exogenous allantoin increases Arabidopsis seedlings tolerance to $\mathrm{NaCl}$ stress and regulates expression of oxidative stress response genes. J. Plant Physiol. 2018, 221, 43-50. [CrossRef]

20. Liang, D.; Gao, F.; Ni, Z.; Lin, L.; Deng, Q.; Tang, Y.; Wang, X.; Luo, X.; Xia, H. Melatonin improves heat tolerance in kiwifruit seedlings through promoting antioxidant enzymatic activity and glutathione S-transferase transcription. Molecules 2018, $23,584$. [CrossRef]

21. Shukla, P.S.; Mantin, E.G.; Adil, M.; Bajpai, S.; Critchley, A.T.; Prithiviraj, B. Ascophyllum nodosum-based biostimulants: Sustainable applications in agriculture for the stimulation of plant growth, stress tolerance, and disease management. Front. Plant Sci. 2019, 10, 655. [CrossRef]

22. De Palma, M.; Salzano, M.; Villano, C.; Aversano, R.; Lorito, M.; Ruocco, M.; Docimo, T.; Piccinelli, A.L.; D'Agostino, N.; Tucci, M. Transcriptome reprogramming, epigenetic modifications and alternative splicing orchestrate the tomato root response to the beneficial fungus Trichoderma harzianum. Hortic. Res. 2019, 6, 1-15. [CrossRef]

23. Fahad, S.; Bano, A. Effect of salicylic acid on physiological and biochemical characterization of maize grown in saline area. Pak. J. Bot. 2012, 44, 1433-1438.

24. Jini, D.; Joseph, B. Physiological mechanism of salicylic acid for alleviation of salt stress in rice. Rice Sci. 2017, 24, 97-108. [CrossRef]

25. Wang, Y.; Gu, W.; Meng, Y.; Xie, T.; Li, L.; Li, J.; Wei, S. $\gamma$-Aminobutyric acid imparts partial protection from salt stress injury to maize seedlings by improving photosynthesis and upregulating osmoprotectants and antioxidants. Sci. Rep. 2017, 7, 1-13.

26. Abido, W.A.E.; Allem, A.; Zsombic, L. Effect of gibberellic acid on germination of six wheat cultivars under salinity stress levels. Asian J. Biol. Sci. 2019, 12, 51-60. [CrossRef]

27. La, V.H.; Lee, B.R.; Islam, M.; Mamun, M.; Park, S.H.; Bae, D.W.; Kim, T.H. Characterization of Glutamate-Mediated Hormonal Regulatory Pathway of the Drought Responses in Relation to Proline Metabolism in Brassica napus L. Plants 2020, 9, 512. [CrossRef]

28. Qiu, X.M.; Sun, Y.Y.; Ye, X.Y.; Li, Z.G. Signaling role of glutamate in plants. Front. Plant Sci. 2020, 10, 1743. [CrossRef]

29. Matin, M.A.; Islam, Q.M.S.; Huque, S. Profitability of lentil cultivation in some selected sites of Bangladesh. Bangladesh J. Agric. Res. 2018, 43, 135-147. [CrossRef]

30. DAE. Krishi Dairy; Agricultural Information Service, Ministry of Agriculture, Government of People's Republic of Bangladesh: Dhaka, Bangladesh, 2018.

31. Foti, C.; Khah, E.M.; Pavli, O.I. Germination profiling of lentil genotypes subjected to salinity stress. Plant Biol. 2019, 21, 480-486. [CrossRef] [PubMed]

32. Andrews, M.; Andrews, M.E. Specificity in legume-rhizobia symbioses. Int. J. Mol. Sci. 2017, 18, 705. [CrossRef] [PubMed]

33. Harb, A.; Ali, S.; Alhaija, A.A. Possible mechanisms of increasing salt tolerance in lentil plants after pre-exposure to low salt concentration. Russ. J. Plant Physiol. 2017, 64, 478-485. [CrossRef]

34. Hossain, M.S.; Abdelrahman, M.; Tran, C.D.; Nguyen, K.H.; Chu, H.D.; Watanabe, Y.; Hasanuzzaman, M.; Mohsin, S.M.; Fujita, M.; Tran, L.S.P. Insights into acetate-mediated copper homeostasis and antioxidant defense in lentil under excessive copper stress. Environ. Pollut. 2020, 258, 113544. [CrossRef]

35. Kan, C.C.; Chung, T.Y.; Wu, H.Y.; Juo, Y.A.; Hsieh, M.H. Exogenous glutamate rapidly induces the expression of genes involved in metabolism and defense responses in rice roots. BMC Genom. 2017, 18, 186. [CrossRef]

36. Gong, M.; Chen, B.O.; Li, Z.G.; Guo, L.H. Heat-shock-induced cross adaptation to heat, chilling, drought and salt stress in maize seedlings and involvement of $\mathrm{H}_{2} \mathrm{O}_{2}$. J. Plant Physiol. 2001, 158, 1125-1130. [CrossRef]

37. Wellburn, A.R. The spectral determination of chlorophylls a and $b$, as well as total carotenoids, using various solvents with spectrophotometers of different resolution. J. Plant Physiol. 1994, 144, 307-313. [CrossRef]

38. Bates, L.S.; Waldren, R.P.; Teare, I.D. Rapid determination of free proline for water-stress studies. Plant Soil 1973, $39,205-207$. [CrossRef]

39. Dionisio-Sese, M.L.; Tobita, S. Antioxidant responses of rice seedlings to salinity stress. Plant Sci. 1998, 135, 1-9. [CrossRef]

40. Heath, R.L.; Packer, L. Photoperoxidation in isolated chloroplasts: I. Kinetics and stoichiometry of fatty acid peroxidation. Arch. Biochem. Biophys. 1968, 125, 189-198. [CrossRef]

41. Keramat, B.; Kalantari, K.M.; Arvin, M.J. Effects of methyl jasmonate treatment on alleviation of cadmium damages in soybean. J. Plant Nutr. 2010, 33, 1016-1025. [CrossRef]

42. Yang, S.H.; Wang, L.J.; Li, S.H. Ultraviolet-B irradiation-induced freezing tolerance in relation to antioxidant system in winter wheat (Triticum aestivum L.) leaves. Environ. Exp. Bot. 2007, 60, 300-307. [CrossRef]

43. Noctor, G.; Mhamdi, A.; Foyer, C.H. Oxidative stress and antioxidative systems: Recipes for successful data collection and interpretation. Plant Cell Environ. 2016, 39, 1140-1160. [CrossRef] [PubMed]

44. Bradford, M.M. A rapid and sensitive method for the quantitation of microgram quantities of protein utilizing the principle of protein-dye binding. Anal. Biochem. 1976, 72, 248-254. [CrossRef]

45. Nahar, K.; Hasanuzzaman, M.; Rahman, A.; Alam, M.; Mahmud, J.A.; Suzuki, T.; Fujita, M. Polyamines confer salt tolerance in mung bean (Vigna radiata L.) by reducing sodium uptake, improving nutrient homeostasis, antioxidant defense, and methylglyoxal detoxification systems. Front. Plant Sci. 2016, 7, 1104. [CrossRef]

46. Giannakoula, A.; Ilias, I.F.; Dragišić-Maksimović, J.J.; Maksimović, V.M.; Živanović, B.D. Does overhead irrigation with salt affect growth, yield, and phenolic content of lentil plants? Arch. Biol. Sci. 2012, 64, 539-547. [CrossRef] 
47. Jin, X.; Liu, T.; Xu, J.; Gao, Z.; Hu, X. Exogenous GABA enhances muskmelon tolerance to salinity-alkalinity stress by regulating redox balance and chlorophyll biosynthesis. BMC Plant Biol. 2019, 19, 1-15. [CrossRef] [PubMed]

48. Kerchev, P.; van der Meer, T.; Sujeeth, N.; Verlee, A.; Stevens, C.V.; Van Breusegem, F.; Gechev, T. Molecular priming as an approach to induce tolerance against abiotic and oxidative stresses in crop plants. Biotechnol. Adv. 2020, 40, 107503. [CrossRef] [PubMed]

49. Hossain, M.S.; Alam, M.U.; Rahman, A.; Hasanuzzaman, M.; Nahar, K.; Al Mahmud, J.; Fujita, M. Use of iso-osmotic solution to understand salt stress responses in lentil (Lens culinaris Medik). S. Afr. J. Bot. 2017, 113, 346-354. [CrossRef]

50. Hossain, M.S.; Hasanuzzaman, M.; Sohag, M.M.H.; Bhuyan, M.B.; Fujita, M. Acetate-induced modulation of ascorbate: Glutathione cycle and restriction of sodium accumulation in shoot confer salt tolerance in Lens culinaris Medik. Physiol. Mol. Biol. Plants 2019, 25, 443-455. [CrossRef]

51. Sh Sadak, M.; Abdelhamid, M.T.; Schmidhalter, U. Effect of foliar application of amino acids on plant yield and some physiological parameters in bean plants irrigated with seawater. Acta Biol. Colomb. 2015, 20, 141-152.

52. Szabados, L.; Savouré, A. Proline: A multifunctional amino acid. Trend. Plant Sci. 2010, 15, 89-97. [CrossRef]

53. Yildiz, M.; Terzi, $\mathrm{H}$. Effect of $\mathrm{NaCl}$ stress on chlorophyll biosynthesis, proline, lipid peroxidation and antioxidative enzymes in leaves of salt-tolerant and salt-sensitive barley cultivars. J. Agric. Sci. 2013, 19, 79-88.

54. Acosta-Motos, J.R.; Ortuño, M.F.; Bernal-Vicente, A.; Diaz-Vivancos, P.; Sanchez-Blanco, M.J.; Hernandez, J.A. Plant responses to salt stress: Adaptive mechanisms. Agronomy 2017, 7, 18. [CrossRef]

55. Qados, A.M.A. Effect of salt stress on plant growth and metabolism of bean plant Vicia faba (L.). J. Saudi Soc. Agric. Sci. 2011, 10, 7-15.

56. Rahman, M.M.; Rahman, M.A.; Miah, M.G.; Saha, S.R.; Karim, M.A.; Mostofa, M.G. Mechanistic insight into salt tolerance of Acacia auriculiformis: The importance of ion selectivity, osmoprotection, tissue tolerance, and $\mathrm{Na}^{+}$exclusion. Front. Plant Sci. 2017, 8, 155. [CrossRef]

57. Pandey, A.K.; Sengar, R.S. Effect of salt stress on salt tolerant indices of morpho-physiological traits and yield attributes of lentil (Lens culinaris Medik.). Int. J. Chem. Stud. 2020, 8, 2292-2301. [CrossRef]

58. Miller, G.A.D.; Suzuki, N.; Ciftci-Yilmaz, S.U.L.T.A.N.; Mittler, R.O.N. Reactive oxygen species homeostasis and signalling during drought and salinity stresses. Plant Cell Environ. 2010, 33, 453-467. [CrossRef] [PubMed]

59. Cavalcanti, F.R.; Lima, J.P.M.S.; Ferreira-Silva, S.L.; Viégas, R.A.; Silveira, J.A.G. Roots and leaves display contrasting oxidative response during salt stress and recovery in cowpea. J. Plant Physiol. 2007, 164, 591-600. [CrossRef]

60. Rajendra, F.M.; Kristiani, L.S.; Ariviani, S. Elicitation under salinity stress increases flavonoid content and antioxidant activity in cowpea (Vigna unguiculata) sprouts. IOP Conf. Ser. Mater. Sci. Eng. 2019, 633, 012034. [CrossRef]

61. Rahman, M.M.; Mostofa, M.G.; Rahman, M.A.; Islam, M.R.; Keya, S.S.; Das, A.K.; Miah, M.G.; Kawser, A.R.; Ahsan, S.M.; Hashem, A.; et al. Acetic acid: A cost-effective agent for mitigation of seawater-induced salt toxicity in mung bean. Sci. Rep. 2019, 9, 1-15. [CrossRef]

62. Bilova, T.; Paudel, G.; Shilyaev, N.; Schmidt, R.; Brauch, D.; Tarakhovskaya, E.; Milrud, S.; Smolikova, G.; Tissier, A.; Vogt, T.; et al. Global proteomic analysis of advanced glycation end products in the Arabidopsis proteome provides evidence for age-related glycation hot spots. J. Biol. Chem. 2017, 292, 15758-15776. [CrossRef] [PubMed]

63. Gupta, B.K.; Sahoo, K.K.; Ghosh, A.; Tripathi, A.K.; Anwar, K.; Das, P.; Singh, A.K.; Pareek, A.; Sopory, S.K.; Singla-Pareek, S.L. Manipulation of glyoxalase pathway confers tolerance to multiple stresses in rice. Plant Cell Environ. 2018, 41, 1186-1200. [CrossRef]

64. Nahar, K.; Hasanuzzaman, M.; Alam, M.M.; Fujita, M. Roles of exogenous glutathione in antioxidant defense system and methylglyoxal detoxification during salt stress in mung bean. Biol. Plant. 2015, 59, 745-756. [CrossRef]

65. Rajwanshi, R.; Kumar, D.; Yusuf, M.A.; DebRoy, S.; Sarin, N.B. Stress-inducible overexpression of glyoxalase I is preferable to its constitutive overexpression for abiotic stress tolerance in transgenic Brassica juncea. Mol. Breed. 2016, 36, 1-15. [CrossRef]

66. Li, Z.G.; Duan, X.Q.; Min, X.; Zhou, Z.H. Methylglyoxal as a novel signal molecule induces the salt tolerance of wheat by regulating the glyoxalase system, the antioxidant system, and osmolytes. Protoplasma 2017, 254, 1995-2006. [CrossRef] [PubMed]

67. Gill, S.S.; Tuteja, N. Reactive oxygen species and antioxidant machinery in abiotic stress tolerance in crop plants. Plant Physiol. Biochem. 2010, 48, 909-930. [CrossRef] [PubMed]

68. Mishra, P.; Bhoomika, K.; Dubey, R.S. Differential responses of antioxidative defense system to prolonged salinity stress in salt-tolerant and salt-sensitive Indica rice (Oryza sativa L.) seedlings. Protoplasma 2013, 250, 3-19. [CrossRef]

69. Fan, D.; Subramanian, S.; Smith, D.L. Plant endophytes promote growth and alleviate salt stress in Arabidopsis thaliana. Sci. Rep. 2020, 10, 1-18. [CrossRef]

70. Foyer, C.H.; Noctor, G. Ascorbate and glutathione: The heart of the redox hub. Plant Physiol. 2011, 155, 2-18. [CrossRef]

71. Pandey, P.; Singh, J.; Achary, V.; Reddy, M.K. Redox homeostasis via gene families of ascorbate-glutathione pathway. Front. Environ. Sci. 2015, 3, 25. [CrossRef]

72. Gill, S.S.; Anjum, N.A.; Hasanuzzaman, M.; Gill, R.; Trivedi, D.K.; Ahmad, I.; Pereira, E.; Tuteja, N. Glutathione and glutathione reductase: A boon in disguise for plant abiotic stress defense operations. Plant Physiol. Biochem. 2013, 70, 204-212. [CrossRef]

73. Tepe, H.D.; Aydemir, T. Protective effects of $\mathrm{Ca}^{2+}$ against $\mathrm{NaCl}$ induced salt stress in two lentil (Lens culinaris) cultivars. Afr. J. Agric. Res. 2015, 10, 2389-2398. 
74. Kibria, M.G.; Hossain, M.; Murata, Y.; Hoque, M.A. Antioxidant defense mechanisms of salinity tolerance in rice genotypes. Rice Sci. 2017, 24, 155-162. [CrossRef]

75. Doğan, M. Antioxidative and proline potentials as a protective mechanism in soybean plants under salinity stress. Afr. J. Biotechnol. 2011, 10, 5972-5978.

76. James, R.A.; Blake, C.; Byrt, C.S.; Munns, R. Major genes for $\mathrm{Na}^{+}$exclusion, Nax1 and Nax2 (wheat HKT1; 4 and HKT1; 5), decrease $\mathrm{Na}^{+}$accumulation in bread wheat leaves under saline and waterlogged conditions. J. Exp. Bot. 2011, 62, 2939-2947. [CrossRef] [PubMed]

77. Zhou, Y.; Diao, M.; Chen, X.; Cui, J.; Pang, S.; Li, Y.; Hou, C.; Liu, H.Y. Application of exogenous glutathione confers salinity stress tolerance in tomato seedlings by modulating ions homeostasis and polyamine metabolism. Sci. Hortic. 2019, $250,45-58$. [CrossRef]

78. Ma, L.; Zhang, H.; Sun, L.; Jiao, Y.; Zhang, G.; Miao, C.; Hao, F. NADPH oxidase AtrbohD and AtrbohF function in ROS-dependent regulation of $\mathrm{Na}^{+} / \mathrm{K}^{+}$homeostasis in Arabidopsis under salt stress. J. Exp. Bot. 2012, 63, 305-317. [CrossRef] [PubMed]

79. Hasegawa, P.M. Sodium $\left(\mathrm{Na}^{+}\right)$homeostasis and salt tolerance of plants. Environ. Exp. Bot. 2013, 92, 19-31. [CrossRef]

80. Singh, D.; Singh, C.K.; Kumari, S.; Singh Tomar, R.S.; Karwa, S.; Singh, R.; Singh, R.B.; Sarkar, S.K.; Pal, M. Discerning morphoanatomical, physiological and molecular multiformity in cultivated and wild genotypes of lentil with reconciliation to salinity stress. PLOS ONE 2017, 12, e0177465.

81. Wang, X.; Wang, S.; Chen, Z.; Gong, B.; Wang, X. Effects of exogenous polyamines on nitrate tolerance in cucumber. Russ. J. Plant Physiol. 2016, 63, 549-557. [CrossRef]

82. Rahman, A.; Nahar, K.; Hasanuzzaman, M.; Fujita, M. Calcium supplementation improves $\mathrm{Na}^{+} / \mathrm{K}^{+}$ratio, antioxidant defense and glyoxalase systems in salt-stressed rice seedlings. Front. Plant Sci. 2016, 7, 609. [CrossRef] 